\title{
Native American Death Taboo: Implications for Health Care Providers
}

\section{Authors: Yoshiko Yamashita Colclough}

This is a postprint of an article that originally appeared in American Journal of Hospice \& Palliative Medicine on July 2017. https://dx.doi.org/10.1177/1049909116638839

Colclough, Yoshiko Yamashita. "Native American Death Taboo: Implications for Health Care Providers." American Journal of Hospice \& Palliative Medicine 34, no. 6 (July 2017): 584-591. DOI: $10.1177 / 1049909116638839$.

Made available through Montana State University's $\underline{\text { ScholarWorks }}$ 


\title{
Native American Death Taboo: Implications for Health Care Providers
}

\author{
Yoshiko Yamashita Colclough, PhD, RN'
}

\begin{abstract}
This study was conducted to highlight Native American (NA) perspectives on death taboo in order to examine the cultural appropriateness of hospice services for NA patients, if any. Searching literature that addressed taboo and death from historical, psychological, sociological, and anthropological aspects, a comparison of death perspectives was made between NAs and European Americans. A culturally sensitive transition from palliative care to hospice care was suggested for NA patients and their family.
\end{abstract}

\section{Keywords}

end of life, death, native American, taboo, hospice

\section{Introduction}

Hospice care is considered as a gold standard for quality endof-life care. Its compassionate multidisciplinary team approach has proved effective physically, emotionally, and financially to alleviate pain and suffering and to further offer holistic comfort care to the recipients and their families. ${ }^{1-4}$ Its growth has been gradual but steady, from only 1 facility in 1974 to 5800 facilities in 2013 in the United States. ${ }^{5}$ Hospice care facilities served on $44.6 \%$ of all deaths in the United States. However, its use by Native American (NA) patients was only $0.3 \%$ of all deaths under the hospice service, when compared to $0.9 \%$ presentation of the NA populations in the total population. ${ }^{6}$ When NA patients live in rural or frontier areas, their use of hospice service is much less likely in part due to scarce availability of such services. ${ }^{7}$

Barriers for hospice use by NA patients are not only the limited access to hospice services (ie, scarcity, lack of transportation, and no coverage with the Indian Health Service benefit) but also their traditional worldview (spiritual, social, psychological, and emotional aspects) to end-of-life care and the requirements of hospice enrollment. ${ }^{8-10}$ It is generally known that discussing death and dying among NAs is a violation of cultural value or taboo. Our assessment study supports that notion. ${ }^{11,12}$ Once a hospice philosophy that cherishes a holistic approach to comfort care is shared with the study participants, however, they are pleased to know the similarity of the holistic approach to their cultural healing processes. ${ }^{12,13}$

Another challenge for NAs to choose hospice care that our assessment study implied was a requirement of hospice care. With modern advanced technologies and medicine, United States society has changed where the law requires clear endof-life care preference. ${ }^{14}$ For those who hold the death taboo perception for religious or traditional reasons, reconciliation of the taboo perception of discussing end-of-life affairs and the requirement of its result is a challenging task. Moreover, the study participants could not negotiate 2 conflicts in making a hospice choice: (1) the acknowledgment of a patient's life being limited to within 6 months and (2) their associated feeling of guilt that the hospice choice means giving up hope for the patient's cure/survival. ${ }^{11,12}$ To address hospice disparity for NA patients, understanding their perception of death taboo in depth is paramount for assessing their end-of-life care preference. Then, finding a clue to alleviate the quandary is the first logical step. As a foundation of this approach, the purpose of this article is to share the death taboo perception from historical, psychological, sociological, and anthropological perspectives. Any differences in the death taboo perception between NAs (the literature included First Nation people in Canada) and European Americans are highlighted. Finally, cultural appropriateness of the hospice movement for the NA population is discussed.

\section{Definition of Taboo}

The word "taboo" can be simply defined as not being acceptable to talk about or do. ${ }^{15}$ According to encyclopedias, the word taboo is derived from Polynesian "marked thoroughly"

\footnotetext{
'Montana State University, Bozeman, MT, USA

Corresponding Author:

Yoshiko Yamashita Colclough, PhD, RN, Montana State University, Bozeman, College of Nursing, POBox 173560, Bozeman, MT 59717-3560, USA.

Email: yoshikoc@montana.edu
} 
and associated with a sense of sacred and religious observance. ${ }^{16,17}$ Taboo is considered to be a creation of the "gradual outgrowth of animistic belief" in a mysterious spiritual potency to injure by the tabooed persons, objects, or places without any moral implications. Since the offended spirits could cause injury that may lead to sickness, disease, and death, an offending action to spirits becomes a taboo.

Taboo is also imposed by priests or indigenous tribal chiefs for political reasons. It can be beneficial to a community as a whole for safety in case of contagious diseases or exploitative to the imposers, permanent or temporary and private or public. ${ }^{16,17}$ Various ceremonies such as worships and sacrifices conducted by priests and chiefs are developed to calm disturbed spirits and to minimize a negative effect of taboo. Later, a moral account of taboo is introduced as a categorical imperative. ${ }^{4}$ According to Hopkins, all moral laws as well as civilized practices including caste are deduced from taboos. ${ }^{4}$ This connection of taboo with morality appears to reinforce righteousness of taboo in people's minds. Although the idea that reasoning makes human beings special in nature is developed in the Ancient Greek period, such an idea did not gain popularity until the 17 th to 18 th century in modern societies. ${ }^{18}$

Based on the above-mentioned explanation, taboo can be defined as something necessarily differentiated or excluded from an ordinary life to prevent undesirable phenomena from happening with awe-inspiring invisible power. Taboo is a threat- or fear-provoking word. The purpose appears to stabilize a society.

\section{Brief Historical View on Death and Associated Taboo}

Death as a taboo topic appears even in Ancient Greece. ${ }^{19}$ According to Sandin, a central feature of the Greek religion of the Classical period regards death as impurity. In those days (eighth to sixth century BC), homicides were abundant through political conflicts, military training, and athletic competition besides war and accidents. ${ }^{20}$ Revenge was a family matter that led to a chain reaction. Impurity considered as "automatically transmittable and infectious"20(p126) appeared to illustrate human nature. To subdue such reactions, lawgivers modified the secular law to make "legal distinctions and the differentiated attitude towards afterlife" ${ }^{20(p 128)}$ based on whether an intention of killing was internally pure (eg, self-defense) or not. Purification was necessary to rid pollution from the person or the community, since pollution can eventually cause a disrespectful action to the Gods or a failure to carry out a proper religious obligation. ${ }^{21}$

People in Ancient Egypt, Rome, and China believed in an afterlife, and such belief led to body preservation (eg, mummification), human/animal sacrifice, monument building, a coin in the mouth, and food offering. ${ }^{22}$ These practices suggest that people in those days may have believed in immortality since nobody experienced afterlife. ${ }^{23}$ On the other hand, people in Ancient Mesopotamia feared death because they believed in a dismal afterlife with no drinkable water given and havoc caused by evil spirits. ${ }^{22}$ This fear resulted in a custom to offer water to the deceased. Further, death was considered unnatural as a result of sorcery except when caused by violence or accident. ${ }^{23}$ In either case, death was considered as an undesirable event, a type of total uncleanliness. ${ }^{23}$ Thus, its explicit expression is forbidden or sacrilegious. Here, death is connected with taboo.

\section{Historical Native American View on Death and Taboo}

Before describing NAs' perspectives, 2 remarks are appropriate to emphasize firmly. One is heterogeneity of the tribal nations. While common themes in terms of death exist among NAs, each tribe, individual, and family/clan develop their own values and behaviors associated with death. Thus, generalized statements in this article need to be understood cautiously. Another is the perspectives of the past literature, which may not reflect on perspectives of then-NAs, rather, instead, may reflect more on those of the authors who are more likely Europeans. ${ }^{24}$ This article used the references as they are written, since the source of this article is literature and not oral references.

Perception of death among the NAs varies, ${ }^{25,26}$ but people in most tribes traditionally conceive death as part of the natural life cycle. The majority of their deaths were caused by accidents, disease, hunger, and war prior to the European encounter. ${ }^{27-29}$ It was surprising to find references of NA's life expectancy due to their oral tradition. Life expectancy at birth was reported to be between 25 and 35 years and few survived past age $50 .{ }^{28,30}$ However, famous tribal chiefs, such as those in the "Indian Spirit," 31 stories from "Pretty Shield,",32 and anecdotal stories about grand- and great grand-parents would dispute such referenced numbers. Children were exposed to deaths and the grief process through attending rituals and funerals. ${ }^{25,26,33-35}$ Thus, death was not a rare event for NAs. In the early investigation of this article, a more confusing statement was found. In the Blackfeet tradition, "sickness and death came to Earth only after Creator Sun saw that human needed to learn compassion."27(p43) How then did death, the life event of cultivating compassion, become a taboo topic?

To investigate NAs' perspectives on death, understanding their way of life, spirituality, and cosmology is a must. ${ }^{25}$ Although there are some exceptions, ${ }^{24,34}$ the majority of NAs believe in the Creator, Great Spirit, or God which govern all living creatures equally including human beings. ${ }^{24,25,35,36}$ A clear difference from other religions including Christianity is in the position of humans. While NAs place humans equally with other living creatures in nature, the view of non-NAs places humans to be superior to others. ${ }^{35}$ In addition, NAs believe that all things and beings are imbued with spirits or souls. ${ }^{31,37,38}$

From this worldview, spirituality is a core of NAs. It sounds and fits better to explain their values and belief systems rather than calling it religion, since spirituality has more individual aspects to it. ${ }^{31,37}$ Clear evidence was not identified if the NA 
used an equivalent word to religion, but it might have started when the Native American Church, which indicates Peyote Religion, was recognized around $1917,{ }^{34}$ although Utter states that references to Peyote Religion in Mexico go back to 1560 and in Pueblo tribe in New Mexico in the 1630s. ${ }^{24}$

Spirit or soul can be interpreted as an energy source or life force from the Creator. ${ }^{39}$ Two types of spirits, physical and spiritual (or life soul and intellect soul), ${ }^{30}$ are commonly used to explain their concept of life and death. Native Americans communicate directly to the Creator ${ }^{36}$ or through spirits or ceremonies. ${ }^{31}$ While death means death of physical spirit, spiritual one continues to exist. It passes over into the spiritual world, where the Creator and other spirits such as those of deceased families and relatives reside. Death is a transition not the end of life. ${ }^{31}$ Some believe reincarnation as these spirits continuing the circle of life and death. ${ }^{25,37}$ Therefore, death is not something to be feared for or to worry about. It is the Creator's responsibility/territory to determine each creature's fate. Thus, people talking about death and dying is disrespectful to and in violation of or blasphemy against the Creator. This insight can lead to the death taboo perception. Rather, NA's attitudes are to focus on life, which is to live thankfully 1 day at a time and ethically with harmony while on the Earth. ${ }^{10,25,36}$

Another possible explanation of death taboo is based on another aspect of spirits. Spiritual ceremonies of NAs are instilled with a concept that "an invisible force pervades the universe,"24(p145) and any place, being, or object with the force can have supernatural power ${ }^{37}$ similar to the historical view of the other parts of the world. ${ }^{16,17,35}$ What sounds different from the Ancient world was that certain taboos were protections for "someone who was not in a sacred state" ${ }^{24(\mathrm{p} 145)}$ from the power. Those in 3 life crises, birth, puberty, and death, are considered to be in these unsacred states and dealt with by rituals because they are subject to supernatural power, not because of uncleanliness. The NA rituals include seclusion, withdrawal, and spiritual purification to keep themselves and others safe. Otherwise, the souls of dead people or hunted animals for example might desire company or revenge. ${ }^{24}$

One final possible explanation for the death taboo is related to language and communication. While accepting death as it is, spiritual NAs with oral tradition must have been influenced by a perception of power of word and the power that may be possessed by the dead. Talking about negative topics including death and a deceased name is suppressed. ${ }^{8,26,40}$ Similar to Ancient Mesopotamians, members of some tribes fear death. ${ }^{22,30,40,41}$ For example, the report for the Comanche Tribe states that their fear of the evil spirits and the dying ghost, which were believed to cause death, was so enormous that some cases of elders with a medically hopeless condition were "thrown away" or deserted by all except faithful relatives for others' safety. ${ }^{26(\mathrm{p} 149)}$ This unusual practice to respectful elders indicates a tremendous degree of fear. Death is meaningful as well as fearful. The perception related to oral power may have resulted in the death taboo. ${ }^{10,30}$
In terms of grieving, sadness of losing a loved one is shared among all human beings. However, NAs appear to express such feelings in a more straightforward manner than European Americans do. Differences may be in a ceremonial grieving process. Unlike Western societies where emotional expression of grieving is suppressed as explained later, death and its grieving is a significant event in NAs' life and a profound communal event, since death relates to the Creator directly. Ceremonies including an immediate after-death event, funeral/burial (same day ${ }^{26}$ to $4-6$ days $^{38,41}$ ), Potlatch, ${ }^{38,42}$ give away, ${ }^{26,41,42}$ the Feast of the Dead, ${ }^{30}$ and so on once prohibited, could be participated in by 50 to 1000 people traditionally to express respect for the deceased. ${ }^{41}$ Songs, dances, and oratory are used as support and entertainment to change mode of mourners. ${ }^{38}$

Death is neither welcomed nor openly discussed since it, in part, means a loss of the most preciously valued social relations, ${ }^{30}$ but it is accepted as a reality. ${ }^{10,33,36}$ Similar to the early Middle Ages, several publications state that the dying know their imminent death and prepare the spirits to cross over. ${ }^{30,36,39}$ A requirement for the law appeared to start launching cultural differences on discussing end-of-life care preference. . $^{8,43}$

\section{Trends in Views of Death by European Americans}

People in the past often experienced others' deaths much more than those in modern society due to a short life expectancy. ${ }^{44}$ For example, 22 years was an average life expectancy for a laborer in London in the 19th century. ${ }^{45}$ According to Aries, contemporary (nineteenth to twentieth centuries) American attitudes toward death were rooted in the early Middle Ages (fifth to fifteenth centuries). ${ }^{44}$ Death was a very private, personal event in the context of a death-abundant society. In those days, the dying had an essential right to know about one's own death. He presided over it for preparation and organization of his own death. ${ }^{44}$ In Christian tradition, his preparation for the afterlife is to avoid sin and do a good deed. ${ }^{46}$ When the person was not aware of his fate, a doctor or a spiritual friend took this task of warning him of his dying. He was left alone with God, since he should not be distracted from the care of his soul. Unlike current advanced technologies that focus on a physical aspect of death and dying in life, more religious and spiritual aspects were emphasized to assist the dying person to seek the meaning of life in those days. The dying person used last wills and testaments to express freely his personal warm testimony because, in part, they were a moral necessity to avoid traditional mistrust to the surviving families and relatives. ${ }^{44} \mathrm{~A}$ spiritual friend was charged to spread news of the death. Funeral was a community event. A proper burial was important to avoid lingering death as a ghost and to send him off for afterlife.

Then there was a shift in a death event in the 17th century. ${ }^{44,47}$ Aries explains that this first shift was centered on the relationship between the dying and his family rather than an internal aspect of the dying such as fear of death. Families 
started to be involved in the death event and decisions due to lower awareness of the dying's approaching death because of his social status (ie, job and profession) and lifestyle. As a result, the family started taking responsibility for warning of death to the dying. ${ }^{44}$

However, once being tolerated by family, the process of a loved one's dying, which included warning of impending death and the death itself, became no longer tolerable. Here, family feeling or emotional centrality of the family started being noticed, and the family started alienating the dying and deprived him of information and freedom for the sake of his own good. A paternalistic approach was under way. That is, both family and doctors were obligated to conceal a serious condition of the dying due to a moral requirement that "not to tell the truth" was considered as a "law of love and charity." $44(\mathrm{p} 138)$ This was a start of secrecy. Hence, centrality of the family to a dying process gained absolute trust from the dying, this practice became sacred, and the family was committed to respect the verbal wishes rather than the written wills or letter that may not exist. Whether or not a paternalistic approach to the dying was acceptable depended on the survivors, not the dying. Aries claims that secrecy as avoidance and discretion appeared to be "the modern form of dignity." ${ }^{44(\mathrm{p} 141)}$ Death, once a part of the people's life, reappeared as a taboo topic not because of offended spirits but because of family feelings in the modern era.

Yet, Aries continues to argue that advancement of medicine is also responsible for the perception of death as a taboo topic. As the second factor, modern medicine replaces death by illness in the mind of the sick man and leads people to an illusion that medicine is the answer to everything and that there is absolutely no reason to die. In such a modern society, incurable illnesses such as various types of cancer "force society to ... intensify its customary demands of silence." ${ }^{44(\mathrm{p} 141)}$ Moreover, cure-obligated physicians are more likely hesitant to bring up a discussion of the incurable nature of illnesses and possible death to cure-expecting patients and their families. ${ }^{48}$ This phenomenon may give impetus to a reticence movement that strengthens the taboo perception of discussing death and dying. While current death-abundant and cure-oriented media information helps people focus on others' deaths (ie, an objective view of death) and own health status (limited or chronic), ultimate limitation of the body (ie, a subjective view of own death) is left out. ${ }^{49}$

The third factor, religion or lack of religion, explains death as a taboo topic from a sociological viewpoint. A modern society is characterized as a process of religious disenchantment. ${ }^{49}$ With disenchantment, scientific understanding and rationalization rather than traditional and religious teaching have started to be valued, and science distinguishes evidence-based sources from normative social orders based on religious ethics and taboo. ${ }^{50}$ For example, the Protestant accounts in the 19th century shifted death from a formal religious communal event to a private one, separated from traditionally powerful church, leading to individualization and privatization of death. ${ }^{49-51}$ This privatization or informality of death is partially responsible for the death taboo because traditional or ritual behaviors become "suspect and embarrassing" plus the privatization requires individuals alone to find "the right word and ... gesture" when facing the dying or their death. ${ }^{49(\mathrm{p} 417)}$ Walter elaborates on acceptance and denial of death perception stating that death is "denied by the traditional cultures [or societies due to their belief in afterlife] and by modern individuals. $" 52(\mathrm{p} 306)$

Along with this notion is "the most intense personal pain" that happens when facing loved one's death since modern individuals deny death and "others are unwilling to share it."52(p306) A result is a reluctance to deal with death and dying of others and eventually of self and a hesitation to relate to others. Furthermore, even cynically hedonistic avoidance of death is described. "[D]eath is not to be feared, not because of any moral obligation to overcome the fear it causes, but because it is inevitable and because in fact there is no reason to dread it-only it must absolutely not be thought about, much less spoken about." 44 (p153)

On the contrary, Kellehear brings convincing argument of contesting the death-denial concept from another sociological viewpoint. ${ }^{53} \mathrm{He}$ defines death denial as "avoidance of the reality of death." $53(\mathrm{p} 714)$ It was written in 1984, but some points are intriguing. For example, it is debatable, but he argues that "we do not, indeed cannot, fear the unknown by definition.... we may fear the prospect of death ... fear of life."53(p715) His thesis that Western society is not death denying exemplified his counterexplanation of "religion and our reluctance to speak of death or express open grief." ${ }^{53(\mathrm{p} 718)}$ For religion, he argues that there is no empirical evidence of a belief in God and immortality. For reluctant attitude, he insists that "conversational propriety and emotional reserve in relation to death" are a custom of politeness. ${ }^{53(\mathrm{p} 719)}$

Further, concepts of transcendence and eternity "undermine the death taboo" $11(\mathbf{p} 745)$ in a postmodern society where "the power of the mind and spirit has become a source of reenchantment." ${ }^{51(p 753)}$ The background of these concepts is a New Age movement, eclectic beyond typical religious teaching on top of the self-control idea of death and dying. Here, once a lost opportunity, seeking for the meaning of death has been revived, at least among scholars, academics, and such believers. Additionally, media programs such as "In Our Own Terms" and "Being Mortal" offer openings to the public to reflect own life and death concepts.

In summary, Aries' descriptions are applied here. ${ }^{44}$ In the 5th to 10th centuries, too many deaths deadened the power of death. Two themes that appeared in the following centuries are last judgment in the 12th to 13th centuries (ie, power of church/ Christianity) and the art of dying in the 14th to 15 th centuries, that is, the entire universe seems united, centrality of the dying exists, and death is the place for the realization of self. When involvement of family, individualism, and advances in science and technologies took over, dying and death changed. Death "lost all positive meaning; it has become merely opposite ...

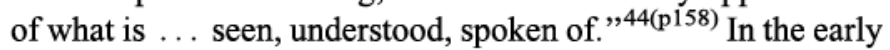
20 th century, dying in ignorance became a moral requirement, 
Table I. Comparison of Death Perspectives Between Native Americans and European Americans.

\begin{tabular}{|c|c|c|}
\hline & Traditional Native Americans & European Americans \\
\hline Death in a life cycle & Circular-importance of family line & Linear-importance of self or individual \\
\hline Reason for death taboo & Tradition: Death and dying are in a sacred realm of the Creator & $\begin{array}{l}\text { Privacy \& dignity: Individualistic society is } \\
\text { valued }\end{array}$ \\
\hline Attitude of death & $\begin{array}{l}\text { Subject to supernatural power; death is unknown so that people } \\
\text { should not worry about it; accept as it is. Navajo: Fear, taboo to } \\
\text { say deceased names, and talk negative thoughts }\end{array}$ & $\begin{array}{l}\text { Fear; more fear to unknown due to no/rare } \\
\text { scientific evidence; can be controlled for } \\
\text { quality of life }\end{array}$ \\
\hline Afterlife & Spiritual world exists & Varies; generally it exists \\
\hline $\begin{array}{l}\text { Visitors while sick or } \\
\text { dying }\end{array}$ & $\begin{array}{l}\text { The more visitors, the more energy and courage a patient receives } \\
\text { to recover/cross over }\end{array}$ & The more visitors, the closer a patient dies \\
\hline $\begin{array}{l}\text { Authority and base of } \\
\text { care/treatment } \\
\text { decision-making }\end{array}$ & $\begin{array}{l}\text { Horizontal; individual autonomy but accompanied family } \\
\text { (cooperation and consensus principle). Compassion }\end{array}$ & Vertical; individual or proxy. Information \\
\hline Communication & Implicit, silence & Explicit \\
\hline Contract & Oral tradition & Signed documentation \\
\hline
\end{tabular}

and happiness, well-being, good health, and youth in society obtained more popularity. This perception made people forget or push away another side of life: sickness, aging, and death. While the new movement is still appearing, discussion of death and dying remains as taboo in the majority of people's minds. 54,55

\section{Comparison of Death Perspectives Between Native Americans and European Americans}

Table 1 is a summary of the comparison of death perspectives between NAs and European Americans. Various individualities should be strongly emphasized, especially for NAs. The values and customs of the traditional culture including spiritual practice, ceremonies, Native American Church, the influence of Christianity, the level of acculturation, and personal experience, will affect their perspectives. ${ }^{10,25}$ Although the descriptions in Table 1 appear to be dichotomous views, rather they mean to be a continuum. Some of NAs and European Americans might cross the lines or fall outside the continuum.

A clear difference is found in the taboo perception of death between NAs and European Americans. While NAs believe death is up to the Creator, European Americans believe it is up to an individual. Hospice movement has been assisting European Americans to the preferable direction for quality of life, which includes a community support (volunteer) component to compromise the individuality focus. Further suggestion for European Americans includes considering the NA view of death to help alleviate pain caused by an inevitable death. Then, what would be a successful intervention for NAs to overcome the death taboo perception?

\section{Discussion}

In summary, death perception has changed throughout human existence. Advancement or convenience of living condition has created the false perception that people concur with most everything and successfully control their environment. Facts and feelings of having overcome difficulties in life shine on 1 side of life: good health, youth, and affluence. Yet this attitude falsely allows people to perceive that death may be avoidable. This perception may be a source of a taboo perception of death. However, death is inevitable.

From NAs' viewpoint, coexistence of the concept of death as a part of life and the taboo perception of discussing death and dying is possible. Their perception on death are as follows: (1) Death is the Creator's realm to determine, not within a range of human control; (2) Soothing evil spirits requires silence to reduce more harm; and (3) Expression of death may trigger another death due to the power of words. Based on understanding of these insights, a sensitive approach to an individual NA may help health-care providers gain rapport during annual physical checks, screenings, or hospital admissions or when a case where hospice care would benefit an NA patient and their family arises.

Health-care providers, especially those who are European Americans, are suggested to expect that establishing initial rapport with NAs would take a considerable amount of time due to difference in communication style, historical trauma, and distrust. This issue is not personal, rather categorical/ racial. On the other hand, this suggestion is based on a stereotype. Instead of being a part of such generalization, with compassion and open heart, each health-care provider can develop his or her own way to connect with NA patient and family.

After establishing initial rapport and continuing it, clarification of the NA patients' view on advanced medical technology is important. A key point is to identify their comfort level on use of medical treatments as a part of the Creator's will or not. Supporting the notions that their preference would differ from their taking control of life and death and invading respectful awe-inspiring secrecy may allow them to express their wishes. 
Several reassurances may be required due to their indirect communication style. It is also a high possibility that their response may be up to their physician, ${ }^{11}$ especially when strong trust is established.

Involvement of all family members who need to be involved in decision-making is another suggestion. Preference of the amount of information to be shared with whom in terms of the patient condition would vary from family to family; then, several meetings may be required. Native Americans may not value knowing all possible information. ${ }^{56} \mathrm{~A}$ culturally competent health-care provider can be appointed as a mediator. When mediating a family meeting, shifting family members' focus from losing precious loved one or fear of death to empowering them to act on what they can do best for the patient at that moment may alleviate their tension. Reminding them of their strengths such as traditional view on death as a part of the life cycle, continuation of spiritual spirit, respect for the patient's wishes, and their value on compassion and comfort could transcend the death taboo perception. While avoiding to use negative expressions and not hesitating to say gently "I don't know" to respond to a question of life expectancy, centering on the patient's wishes at each meeting may assist communicating further.

Introduction of palliative care instead of hospice care may work better to avoid a negative impression, although limited accessibility to palliative care in the current health-care system will be challenging. Compassion is the primary value for both NAs and palliative care. If palliative care could be offered at any stage of illness, the experience of palliative care would hopefully make the step to hospice care easier for patients and families if necessary. Thus, familiarizing or increasing visibility of the word "palliative" is paramount. For instance, any health-care provider can start offering palliative care using the word "palliative" for pain control or just being there to respect their patients. An informal team can be developed when getting together. Balancing informed educational practice with compassionate care will bring satisfaction in both sides. ${ }^{56}$ For the community, the similar minded can demonstrate a community awareness project and support group, further develop a nonprofit organization to train community health workers who can approach individual in a less threatening manner. It will take time, but a magic of oral tradition (ie, word of mouth) could happen. Is hospice movement still a desirable direction for NAs? Of course, yes, as long as it is developed with cultural sensitivity. ${ }^{1-4}$ It is a community movement.

\section{Declaration of Conflicting Interests}

The author(s) declared no potential conflicts of interest with respect to the research, authorship, and/or publication of this article.

\section{Funding}

The author(s) received no financial support for the research, authorship, and/or publication of this article.

\section{References}

1. Aziz NM, Miller JL, Curtis JR. Palliative and end-of-life care research: embracing new opportunities. Nurs Outlook. 2012; 60(6):384-390.

2. Gomes B, Calanzani N, Curiale V, McCrone P, Higginson IJ. Effectiveness and cost-effectiveness of home palliative care services for adults with advanced illness and their caregivers. Cochrane Database Syst Rev. 2013;6:cd007760.

3. Morrison RS, Meier DE. The national palliative care research center and the center to advance palliative care: a partnership to improve care for persons with serious illness and their families. J Pediatr Hematol Oncol. 2011;33(suppl 2): s126-s131.

4. Zimmermann C, Riechelmann R, Krzyzanowska M, Rodin G, Tannock I. Effectiveness of specialized palliative care. JAMA. 2008;299(14):1698-1709.

5. National Hospice and Palliative Care Organization. Growth in US Hospice Programs: 1974 to 2013. Alexandria, VA: National Hospice and Palliative Care Organization; 2015. Web site. http:// www.nhpco.org/sites/default/files/public/Statistics_Research/ ProviderGrowth.pdf. Accessed May 11, 2015.

6. National Hospice and Palliative Care Organization. NHPCO Facts and Figures: Hospice Care in America. Alexandria, VA: National Hospice and Palliative Care Organization; 2014.

7. Kitzes J, Berger L. End-of-life issues for American Indians/ Alaska Natives: insights from one Indian Health Service area. J Palliat Med. 2004;7(6):830-838.

8. Carrese JA, Rhodes LA. Western bioethics on the Navajo reservation: Benefit or harm? JAMA. 1995;274(10):826-829.

9. Kitzes JA, Domer T. Palliative care: an emerging issue for American Indians and Alaskan Natives. J Pain Palliat Care Pharmacother. 2003;17(3-4):201-210.

10. Van Winkle NW. End-of-life decision making in American Indian and Alaska Native culture. In: Braun KL, Pietsch JH, Blanchette PL, eds. Cultural Issues in End-of-Life Decision Making. Thousand Oaks, CA: Sage Publications, Inc.; 2000: 127-146.

11. Colclough YY, Brown GM. End-of-life treatment decision making: American Indians' perspective. Am J Hosp Palliat Care. 2014;31(5):503-512.

12. Colclough YY, Brown GM. American Indians' experiences of lifetThreatening illness and end of life. J Hosp Palliat Nurs. 2014;16(7):404-413.

13. National Cancer Institute \& Indian Health Service [IHS]. EPEC $^{\mathrm{TM}_{-} O}$ with American Indian and Alaska Native Cultural Considerations. 2004; EPEC ${ }^{\mathrm{TM}}$-O curriculum. CD-ROM \& DVD.

14. Patient Self-Determination Act (PSDA). Omnibus Budget Reconciliation Act of 1990. 1990:101-508.

15. Merriam-Webster Online Dictionary. Merriam-Webster's Collegiate $^{\circledR}$ Dictionary, Eleventh Edition 2015; 11 th. Springfield, MA: Merriam-Webster Online Dictionary. Web site. http://www.merriam-webster.com/. Accessed December 4, 2015. 
16. The "Examiner". Americanized Encyclopedia Britannica, Revised and Amended: A Dictionary of Arts, Sciences and Literature; to Which is Added Biographies of Livings Subjects. Vol 9. San Francisco, CA: The "Examiner" the University of California; 1890/2009:5918.

17. Hopkins EW. Taboo. In: Gilman DC, Peck HT, Colby FM, eds. The New International Encyclopaedia. Vol 18. New York, NY: Dodd, Mead and Company; 1905:827.

18. Rachels J. The Elements of Moral Philosophy. Original/8th ed. New York, NY: McGraw-Hill Education; 1986/2014.

19. Sandin P.Herodotus, Dionysus, and the Greek death taboo. The Homeric Hymn to Demeter and the construction of the "chthonic" in Greek literary tradition. Symbolae Osloenses. 2008;83(1): 2-17.

20. Chaniotis A. Greek Ritual Purity from Automatisms to Moral Distinctions. In: Rosch P, Simon U, eds. How Purity Is Made. Wiesbaden, Germany: Harrassowitz Verlag; 2012: 123-139

21. Moulton C. Ancient Greece and Rome: An Encyclopedia for Students [Topic overview]. New York, NY: Holiday House; 1998: 178-180. Web site. http://ic.galegroup.com/ic/whic/ReferenceDetailsPage/ReferenceDetailsWindow?zid $=0769 \mathrm{e} 7 \mathrm{eef519dffc52f95}$ d3e0369f225\&action $=2$ \& catId $=$ \&document $I d=$ GALE $\%$ 7CCX2897200404\&source $=$ Bookmark \&u $=$ tlc 199095657 $\& \mathrm{jsid}=$ fa 7ba44debab824a63058d1a1a67f29c. Accessed December 4, 2015.

22. History. Death in Ancient Civilisations. History of Death. n.d. Web site. http://www.history.co.uk/study-topics/history-ofdeath/death-in-ancient-civilisations. Updated October, 2012. Accessed March 27, 2015.

23. Hastings J, Selbie JA, Gray LH. Encyclopædia of Religion and Ethics: Life and death-Mulla. In: Clark TT, ed. Vol VIII: Life and Death Mulla. New York, NY: Charles Scribner's Sons; 1916:400.

24. Utter J. American Indians: Answers to Today's Questions. Second ed. Norman, OK: University of Oklahoma Press; 2001.

25. Turner-Weeden P. Death and dying from a Native American perspective. Hosp J. 1995;10(2):11-13.

26. Wallace E, Hoebel EA. The Comanches: Lords of the South Plains. Norman, OK: University of Oklahoma Press; 1986.

27. Edwards DD. White Father Medicine and the Blackfeet, 18551955. In: Hildreth ML, Moran BT, eds. Disease and Medical Care in the Mountain West: Essays on Region, History, and Practice. Reno, Las Vegas: University of Nevada Press; 1998: 43-58.

28. Steckel RH, Rose JC. The Backbone of History: Health and Nutrition in the Western Hemisphere. Cambridge, UK: Cambridge University Press; 2005.

29. Nordin KD. Native American Religion. New York City, NY: Encyclopedia of Death and Dying n.d. Web site. http://www. deathreference.com/Me-Nu/Native-American-Religion.html. Accessed November 24, 2015.

30. Trigger BG. The Huron: Farmers of the North. 2nd ed. Fort Worth, TX: Ted Buchholz, Holt Rinehart and Winston, Inc.; 1990.

31. Fitzgerald MO, Fitzgerald J. Indian Spirit. 2nd ed. Blooming, IN: World Wisdom, Inc.; 2006.
32. Linderman FB. Pretty-shield. Books Bison ed. Lincoln, NE: University of Nebraska Press; 2003.

33. Lewis R. Death and dying among the American Indians. In: Parry JK. Social Work Practice with the Terminally Ill: A Transcultural Perspective. Springfield, IL: Charles C Thomas Publisher; 1990: Ch. 1, 23-32.

34. Hoebel AE. The Cheyennes. 2nd ed. New York, NY: Holt, Rinehart and Winston; 1978.

35. Underhill R. Religion among American Indians. Ann Am Acad Polit Soc Sci. 1957;311(1):127-136.

36. Halfe LB. Circle: death and dying from a Native perspective. J Palliat Care. 1989;5(1):37-41.

37. Boyle KH. Death and dying from a Native American spirituality perspective; 2012. Web site. http://demonry.com/1302996. html.

38. Simeone WE. The Northern Athabaskan Potlatch in EastCentral Alaska, 1900-1930. Arctic Anthropol. 1998;35(2): 113-125.

39. Duggleby W, Kuchera S, MacLeod R, et al. Indigenous people's experiences at the end of life. Palliat Support Care. 2015;13(6): 1721-1733.

40. Hanley CE. Navajos. In: Giger JN, ed. Transcultural Nursing: Assessment and Intervention. 6th ed. St. Louis, MO: Elsevier; 2013: 240-259.

41. Brokenleg M, Middleton D. Native Americans: Adapting yet Retaining. In: Irish DP, Lindquist JF, Nelson JJ, eds. Ethnic Variations in Dying, Death, and Grief. Washington, DC: Taylor and Francis; 1993: 101-112.

42. Simeone WE. The Northern Athabaskan Potlatch: The objectification of grief. In: Counts DR, Counts DA, eds. Coping with the Final Tragedy: Cultural Variation in Dying and Grieving. Amityville, NY: The Baywood; 1991:157-167.

43. Kaufert JM, O'Neil JD. Cultural mediation of dying and grieving among Native Canadian Patients in urban hospitals. In: Counts DR, Counts DA, eds. Coping with the Final Tragedy: Cultural Variation in Dying and Grieving. Amityville, NY: The Baywood Publishing; 1991:231-251.

44. Ariès $P$. The reversal of death: Changes in attitudes toward death in Western societies. In: Stannard D, ed. Death in America. Philadelphia, PA: University of Pennsylvania; 1975: 134-158.

45. History. Trends in Death. History of Death. n.d. Web site. http:// www.history.co.uk/study-topics/history-of-death/trends-in-death. Accessed March 27, 2015.

46. Bovey A. Death and the afterlife: how dying affected the living. The Middle Age. n.d. Web site. http://www.bl.uk/the-middleages/articles/death-and-the-afterlife-how-dying-affected-the-living. Accessed March 27, 2015.

47. Gorer G. Death, Greif, and Mourning. Garden City, NY: Doubleday \& Company, Inc.; 1965.

48. Institute of Medicine. Dying in America: Improving Quality and Honoring Individual Preferences near the End of Life. Washington, DC: Institute of Medicine; 2014.

49. Mellor PA, Shilling C. Modernity, self-identity and the sequestration of death. Sociology. 1993;27(3):411-431.

50. Weber M. The Sociology of Religion. 4th ed. Boston, MA: Beacon Press; 1971. 
51. Lee RLM. Modernity, mortality and re-enchantment: the death taboo revisited. Sociology. 2008;42(4):745-759.

52. Walter T. Modern death: taboo or not taboo? Sociology. 1991; 25(2):293-310.

53. Kellehear A. Are we a 'death-denying' society? A sociological review. Soc Sci Med. 1984;18(9):713-723.
54. Chapple A, Ziebland S, Hawton K. Taboo and the different death? Perceptions of those bereaved by suicide or other traumatic death. Sociol Health Illn. 2015;37(4):610-625.

55. Wise J. Dying remains a taboo subject for patients and GPs, finds survey. BMJ. 2012;344.

56. Ventres W, Nichter M, Reed R, Frankel R. Limitation of medical care: an ethnographic analysis. J Clin Ethics. 1993;4(2):134-145. 